\title{
Kolej a tożsamość: postawy narodowościowe kolejarzy na czechosłowackim Śląsku Cieszyńskim w latach 20. XX w.
}

Słowa kluczowe: Śląsk Cieszyński, Czechosłowacja, mniejszości narodowe, kolej żelazna, stosunki polsko-czeskie

Keywords: Teschen Silesia, Czechoslovakia, national minorities, railway, Polish-Czech relations

Railway and identity: national attitudes of railway workers in Czechoslovak Teschen Silesia in the twenties of XXth century

Summary: Article presents the national attitudes of railway workers in the region mostly inhabited by Polish and German minority. Czechoslovak railway administration with the collaboration of nationalistic organizations (especially Matice osvěty lidové pro Těšinsko a Hlučinsko) tried to increase the number of Czech railway workers and demanded from them contribution to the czechization efforts. The administration used the policy of relocation and other means of pressure on workers of Polish and German nationality to convince them to support the Czech cause, especially by sending their children to Czech schools.

W 1920 r. historyczny Śląsk Cieszyński po niemal dwuletnim konflikcie został podzielony pomiędzy Polskę i Czechosłowację. W granicach Czechosłowacji znalazło się kilka linii kolejowych, w tym strategicznie szczególnie istotny śląski odcinek trasy koszycko-bogumińskiej, łączący ziemie czeskie ze Słowacją. Ludność terenów, przez które przebiegała ta kluczowa linia, była przeważnie polska i niemiecka; podobnie wyglądała sytuacja wśród pracowników 
kolejowych. Czechosłowacka administracja zdawała sobie sprawę z tych okoliczności i starała się wzmocnić pozycję Czechów na tym terenie. W projektach polityki narodowościowej uwzględniane były także stosunki narodowościowe na kolei ${ }^{1}$ a urzędy kolejowe sprowadzały na stanowiska na Śląsku Cieszyńskim osoby narodowości czeskiej z innych regionów, część Polaków i Niemców oraz kolejarzy podejrzewanych o poglądy komunistyczne (zazwyczaj także byli to Niemcy lub Polacy) przenosiły zaś poza Śląsk Cieszyński. Wywierały też naciski na zmianę orientacji narodowej kolejarzy. Największa akcja przenoszenia kolejarzy z lat 20. nastąpiła w 1923 roku² $^{2}$.

Czeska administracja kolejowa sceptycznie była nastawiona do tych kolejarzy narodowości czeskiej, którzy pracowali na Śląsku Cieszyńskim jeszcze w czasach austriackich. Nowy zarządca ruchu w Czeskim Cieszynie, Josef Šeda zarzucał im oportunizm, wskazywał, że w czasach austriackich należeli do niemieckich organizacji nacjonalistycznych Nordmark lub Deutscher Schulverein, mieli niemieckie rodziny lub dzieci w niemieckich szkołach ${ }^{3}$. Jego opinie wywoływały sprzeciw miejscowych kolejarzy przyznających się do narodowości czeskiej ${ }^{4}$. Jednak na początku lat 20. administracja kolejowa kilkakrotnie straciła zaufanie do osób, zajmujących wyższe stanowiska, gdy na jaw wychodziła ich przeszłość. Tak było na przykład w przypadku Františka Husički, w latach 20. członka komitetu centralnego MOL, który w czasach austriackich należał do Deutscher

\footnotetext{
${ }^{1}$ Gąsior G., Dwa memoriaty Rudolfa Matouša w sprawie czechosłowackiej polityki na Śląsku Cieszyńskim z 1920 i 1923 r. (w przygotowaniu).

${ }^{2}$ Dokładny opis polityki narodowościowej przedstawiono w planowanym do publikacji tekście: Tenże, Železnice pod zvláštním dohledem: železniční úr̆ady a národnostni otázka v československé části Těšinského Slezska na začátku 20. let. ${ }^{3}$ Archiv Českých drah v Července (dalej AČD), f. Košicko-bohumínská dráha (dalej: KBD), presidiální spisy, krabice 5, inv. jedn. Pres. 85/21, informacja Šedy dla Ministerstwa Kolei z 7 lipca 1921 r.

${ }^{4}$ Ibidem, odpis listu posła Františka Buřivala do ministra kolei Václava Burgera z 29 kwietnia $1921 \mathrm{r}$.
} 
Schulverein ${ }^{5}$. Szanse Emila Poledníka, starającego się o stanowisko zawiadowcy urzędu ruchu w Czeskim Cieszynie, choć uznano go za Czecha godnego zaufania, przekreślił fakt, że miał niemiecką żonę (kandydatury Niemców odrzucano z zasady) ${ }^{6}$.

Kryterium, na podstawie którego nominowano kolejarzy na ważne stanowiska na Śląsku Cieszyńskim, były nie tylko odpowiednie kwalifikacje zawodowe, lecz także postawa narodowa. Od kolejarzy oczekiwano zaangażowania na rzecz czeskiego życia narodowego, odpowiedniego oddziaływania na podwładnych lub kolegów i namawianie ich do wysłania dzieci do czeskich szkół. Krytykowano Czechów zachowujących bierną postawę. Szczególnie zwracali na to uwagę działacze MOL. Toromistrz Štěpán Čouza z Mostów koło Jabłonkowa wraz z tamtejszym proboszczem ks. Josefem Jurošem miał przyczynić się do zwiększenia liczby uczniów w miejscowej czeskiej szkole z 37 do $120^{7}$. Umieszczony kilka miesięcy później w tej miejscowości toromistrz Hrozek swoim brakiem zaangażowania dopuścił zaś, zdaniem działaczy MOL, do tego, że dwanaścioro dzieci jego podwładnych odeszło z czeskiej szkoły ${ }^{8}$.

Czescy kolejarze niechętnie przenosili się na Śląsk Cieszyński, gdzie spotykali się z brakiem życzliwości ze strony mieszkańców, których w dodatku zgodnie z oczekiwaniami przełożonych mieli przekonywać do udziału w czeskim życiu narodowym. Kontroler ruchu z Morawskiej Ostrawy, Lukašík, zwracał uwagę, że Czesi kierowani na Śląsk Cieszyński i w okolice Ostrawy dokładają wszelkich sta-

\footnotetext{
${ }^{5}$ A ČD, f. KBD, presidiální spisy, krabice 4, inv. jedn. Pres 53/21, informacja Koláčka dla Ministerstwa Kolei z 13 września 1921 r.

${ }^{6}$ A ČD, f. KBD, presidiální spisy, krabice 6, inv. jedn. Pres 108/22, ściśle poufne pismo Bohumila Reyneka do Ministerstwa Kolei z 3 sierpnia 1922 r.

${ }^{7}$ A ČD, f. KBD, presidiální spisy, krabice 6, inv. jedn. Pres 51/22, list Metoděja Tesařa do Viktorina Kutača z 10 lutego 1922 r.

${ }^{8}$ A ČD, f. KBD, presidiální spisy, krabice 8, inv. jedn. Pres. 396/22, poufne pismo prezydium MOL do zarządu ruchu Kolei Koszycko- -Bogumińskiej do rąk inż. Reyneka w Czeskim Cieszynie z 25 września 1922 r.
} 
rań, aby odwołano decyzję o ich przeniesieniu i szukają protekcji wpływowych osób ${ }^{9}$. Niechętnie przenosiły się na nowe miejsce także rodziny kolejarzy ${ }^{10}$.

Czescy urzędnicy kolejowi niejednokrotnie stawali na czele miejscowych kół nacjonalistycznego stowarzyszenia Matice osvěty lidové pro Těšínsko a Hlučínsko (dalej: MOL), dążącej do rozbudowy czeskiego szkolnictwa oraz angażującej się w zwalczanie mniejszości narodowych i dążącej do przeciągnięcia mieszkańców do czeskiego obozu. Przykładem takich postaw były osoby Josefa Skřídlovskiego i Vladimíra Janála, pełniących funkcję prezesów koła MOL w Darkowie. Przeniesienie służbowe pierwszego z nich do pobliskich Piotrowic uważano nawet za dowód prześladowań Czechów przez administrację kolejową ${ }^{11}$. Drugi znich, Janál, został wybrany na prezesa darkowskiego koła MOL na walnym zebraniu z 4 marca 1923 r., chociaż wcześniej w obradach koła w ogóle się nie pojawiał ${ }^{12}$. Na kolejnym posiedzeniu od razu też w ostrych słowach zwrócił się do zebranych, że niektórzy podobno uważają go za ,intruza” (vetrelec), zapowiadając ostre kary wobec winnych, jeżeli taka sytuacja się powtórzy ${ }^{13}$. Około połowę miejsc w zarządzie koła obejmowali kolejarze, a więc ludzie zależni od Janála w życiu zawodowym. Jednak po odejściu Janála z Darkowa w 1925 r. natychmiast odnotowano znaczny spadek aktywności członków ${ }^{14}$.

\footnotetext{
${ }_{9}^{9}$ A ČD, f. ̌̌editelství ČSD v Olomouci 1895-1949 (dalej: ǨČSD), krabice-rok 1923 , inv. jedn. 81/pres-23; pismo Lukašíka do wydziału V dyrekcji Czechosłowackich Kolei Państwowych w Ołomuńcu z 18 lipca 1923 r.

${ }^{10}$ A ČD, f. ŘČSD, krabice - rok 1923, inv. jedn. 5/pres-23, poufny list Koláčka do Ministerstwa Kolei z 27 stycznia 1923 r., koncept, odręczne uwagi na temat żony kolejarza Jana Letochy.

${ }^{11}$ A ČD, f. $\breve{R} \breve{C S D}$, krabice - rok 1923, inv. jedn. 26/pres-23, poufne pismo organizacji Svaz národních jednot a matic do prezydium Ministerstwa Kolei z 13 lutego $1923 \mathrm{r}$.

12 Zemský archiv Opava, f. Slezská Matice osvěty lidové 1897-1950, inv.č. 471, księga zapisów koła MOL z Darkowa, zapis z walnego zebrania z 4 marca 1923 r.

${ }^{13}$ Ibidem, zapis z posiedzenia z 22 marca $1923 \mathrm{r}$.

${ }^{14}$ Ibidem, zapisy z posiedzeń z 28 września i 21 października 1925 r.
} 
Czescy urzędnicy kolejowi sporządzali teżnegatywne opinie na temat swoich podwładnych innych narodowości i wnioskowali o ich przeniesienie lub byli źródłem takich informacji dla MOL (o ile sami nie kierowali kołami miejscowymi tego stowarzyszenia). Przykładem-jednym z wielu - był Jan Dvouletý, od 1922 r. zawiadowca stacji w Nawsiu (formalnie stacja nosiła nazwę Jabłonków) i prezes miejscowego koła MOL. Kilka lat później jego zasługi dla sprawy narodowej zostały wspomniane przez innych miejscowych działaczy MOL, w tym czasie Dvouletý zmienił jużjednak swoje podejście, odciął się od tej organizacji i krytykował działania podejmowane przeciw kolejarzom innych narodowości. Dokument działaczy MOL ma charakter denuncjacji i mógł być przejawem osobistych niechęci wśród nawiejskich Czechów, wydaje się jednak, że postawa Dvouletego stanowiła zupełny wyjątek wśród odpowiedzialnych pracowników kolei na czechosłowackim Śląsku Cieszyńskim ${ }^{15}$. Kilka lat później został też odwołany ${ }^{16}$.

Miejscowi kolejarze byli przeważnie narodowości polskiej lub niemieckiej. Na samym początku wyższe stanowiska pełnili przede wszystkim Niemcy, w czasach austriackich często należący do niemieckich organizacji. Również od nich oczekiwano postaw oportunistycznych i poparcia czeskiej sprawy, jeżeli chcieli utrzymać się na stanowisku. Np. Gustav Sturz, zawiadowca stacji w Mostach koło Jabłonkowa przeniósł własne dziecko bez nacisku do czeskiej szkoły, później zawiódł jednak kładzione w nim oczekiwania, gdyż w czasie zapisów szkolnych nie zaangażował się w agitację na rzecz czeskich placówek $^{17}$. Na skutek tego został przeniesiony na Morawy ${ }^{18}$.

${ }^{15}$ ZA Opava, SMOL, inv. č. 418, kart. 72, list działaczy koła MOL w Nawsiu do filii centralnej kancelarii MOL w Czeskim Cieszynie z 14 października [1926 r.].

${ }^{16}$ Státní okresní archiv Frýdek-Místek (dalej: SOAFM), f. Slezská Matice osvěty lidové Bystřice nad Olzou (dalej: SMOL Bystřice nad Olzou), inv. č. 5, k. 1, pismo kolegium powiatowego SMOL dla ziemi jabłonkowskiej do kierownictwa SMOL z 22 maja $1930 \mathrm{r}$. ${ }^{17}$ A ČD, f. KBD, presidiální spisy, krabice 8, inv. jedn. Pres 337/22, poufny list Bohumila Reyneka do Leopolda Šmilauera z 13 października 1922 r.

${ }^{18}$ A ČD, f. KBD, presidiální spisy, krabice 8, inv. jedn. Pres 396/22, zawiadomienie dyrektora Josefa Koláčka dla Sturza o mianowaniu zawiadowcą stacji Hrušky z 4 listopada $1922 \mathrm{r}$. 
Specyficzną grupę stanowili zwolennicy Śląskiej Partii Ludowej, którzy w konflikcie o Śląsk Cieszyński opowiedzieli się za Czechosłowacją, i którzy po rozwiązaniu samorządów w 1920 r. często obejmowali funkcje gminnych komisarzy rządowych. Część z nich sprzeciwiała się tworzeniu czeskich szkół. Wśród nich byli kolejarze, Gabriel Ruśniok z Sibicy i Karol Horzinka (Horsinka) z Końskiej. Pierwszy z nich został przeniesiony w głąb Czech w $1923 \mathrm{r} \cdot{ }^{19} \mathrm{i}$ powrócił do swojej wsi w $1926 \mathrm{r}^{20}$; drugi dostosował się do sytuacji i obiecał wspierać czeską szkołę (uznano jednocześnie, że w Końskiej nie ma innych osób, które mogłyby go zastąpić na stanowisku komisarza ${ }^{21}$.

Wielu kolejarzy było aktywnych w polskim życiu społecznym, należało do polskich organizacji i starało się posyłać swoje dzieci do polskich szkół. Czeskie organizacje nacjonalistyczne uważały takich ludzi za nielojalnych wobec władz i niebezpiecznych. Polskim kolejarzom zarzucano, że stoją na czele antypaństwowej agitacji, na przykład sprzeciwiają się budowie czeskich szkół i propagują szkoły polskie. W Porębie na czele thumu domagającego się ponownego otwarcia niepotrzebnej polskiej szkoły (zamkniętej w czasie polsko-czeskiego konfliktu) miał stać kolejarz Paweł Mrózek ${ }^{22}$. W 1925 r. w Szonychlu trzech kolejarzy miało swoją agitacją spowodować obniżenie liczby dzieci, które zapisały się do czeskiej placówki, z 65 do $13^{23}$. Kolejarze

${ }^{19}$ A ČD, f. ̌̌ČSD, krabice - rok 1923, inv. jedn. 26/pres-23, poufny raport Koláčka „Přesuny nespolehlivého personálu z Těšínské oblasti“ dla Ministerstwa Kolei z 26 czerwca $1923 \mathrm{r}$.

${ }^{20}$ A ČD, f. ŘČSD, krabice - rok 1926, 69/řed-26, list kierownika szkoły Františka Sudka do posła Václava Sladkiego z 14 września 1926 r.

${ }^{21}$ A ČD, f. ǨČSD, krabice - rok 1923, inv. jedn. 26/pres-23, poufny raport Koláčka „Přesuny nespolehlivého personálu z Těšínské oblasti“ dla Ministerstwa Kolei z 26 czerwca $1923 \mathrm{r}$.

${ }^{22}$ A ČD, f. KBD, presidiální spisy, krabice 5, inv. jedn. Pres. 103/21, skarga prezydium MOL z 2 sierpnia $1921 \mathrm{r}$.

${ }^{23}$ A ČD, f. $\breve{R C}$ SD, krabice - rok 1925, inv. jedn. 67/pres-25, skarga prezydium MOL dla dyrekcji Czechosłowackich Kolei Państwowych w Ołomuńcu z 5 maja $1925 \mathrm{r}$. 
mieli stać na przeszkodzie rozwojowi czeskiej szkoły w Końskiej24, $\mathrm{Nawsiu}^{25}$ i wielu innych miejscowościach ${ }^{26}$.

Niewątpliwie niektórzy kolejarze pełnili ważne funkcje w życiu gminy, ale fakt, że w dokumentach z początku lat 20. to właśnie kolejarze występowali jako najwięksi przeciwnicy czeskiego życia narodowego a jednocześnie ich dzieci stanowiły jedno z głównych źródeł uczniów dla czeskich szkół, wskazuje przede wszystkim na to, że stanowili grupę zawodową zależną od państwa i szczególnie narażoną na naciski. Zapewne więc dlatego to na ich aktywność zwracano główną uwagę.

Kolejarze, którzy przenieśli dzieci do czeskich szkół, unikali represji. W dokumentach pisano, że odbywało się to bez nacisku i zupetnie dobrowolnie. Wymagano też od nich zaangażowania w namawianie innych osób do zrobienia tego samego. Tak było na przykład w przypadku Pawła Cieślara z Sibicy. Według zawiadowcy urzędu ruchu w Czeskim Cieszynie Josefa Laštovicy, udało się dzięki temu zwiększyć liczbę uczniów miejscowej czeskiej szkoły z 18 do 170, głównie o dzieci kolejarzy ${ }^{27}$.

Po wielkiej akcji z 1923 r. sytuacja się ustabilizowała. Część kolejarzy udało się zastraszyć, inni zachowali swoją tożsamość. Niektórzy z kolejarzy, którzy wcześniej ulegli, po kilku latach powracali do poprzedniej narodowości i ponownie przenosili swoje dzieci z czeskich szkół. Już pod koniec 1923 r. działacze MOL skarżyli się na

${ }^{24}$ Národní archiv v Praze (dalej: NA), f. Ministerstvo železnic I, Praha (dalej: MŽ), k. 260, skarga prezydium MOL dla prezydium Ministerstwa Kolei z 13 lutego $1923 \mathrm{r}$.

${ }^{25}$ A ČD, f. KBD, presidiální spisy, krabice 7, inv. jedn. Pres. 221/22, skarga koła MOL w Jabłonkowie z 9 sierpnia $1922 \mathrm{r}$.

${ }^{26}$ Zob. np.: NA, f. MŽ, k. 313, Seznam železničních zrízenců ze stanice Bohumín - nádraží, kteří vyvíjejí ve svém bydlišti podvratnou činnost proti českému národu a čsl. republice.

${ }^{27}$ A ČD, f. $\breve{R}$ ČSD, krabice - rok 1923, inv. jedn. 26/pres-23, sdělení Laštovicy pro Ředitelství ČSD v Olomouci z 7. července 1923 r., innym powodem wzrostu liczby dzieci w czeskiej szkole było przeniesienie komisarza administracyjnego Ruśniaka. 
takie przypadki. Np. Franciszek Chruszcz (w dokumencie: František Chruscz) już po przewrocie (czyli po 1920 r.) oddał swoje dzieci do czeskiej szkoły, ale gdy zobaczyt, że nic mu się nie stanie, znowu dat swoje dzieci do prywatnej polskiej szkoty i wszczą wściekta agitacje podczas zapisów szkolnych, w kwestii śpiewu na pogrzebach i w kościele, a zwłaszcza podczas ostatnich wyborów atakując czeski naród i nasza republikę $e^{28}$.

Wydaje się, że w drugiej połowie lat 20. presja nieco osłabła. Działania z 1923 r. spełniły swój cel, nie można zaś było wymienić wszystkich kolejarzy ze Śląska Cieszyńskiego na Czechów, gdyż byłoby to bardzo skomplikowane logistycznie i w zbyt jaskrawy sposób naruszałoby prawa mniejszości narodowych zabezpieczone w czechosłowackiej konstytucji. Część kolejarzy ulegała presji częściowo, wysyłając do czeskiej szkoły tylko jedno lub dwoje dzieci. Wiele takich postaw można dostrzec $\mathrm{w}$ doniesieniach działaczy $\mathrm{MOL}^{29}$. Pod koniec lat 20. działacze MOL alarmowali, że autorytet państwa upada. Kolejarze mający dzieci w czeskich szkołach byli podobno obiektem drwin ze strony kolegów, którzy wskazywali, że nic z tego nie mają, a tym, którzy wysyłają dzieci do polskich szkół nic się nie może stać. Po tym, gdy swoje dzieci do polskiej szkoły przeniósł urzędnik kolejowy Rusz z Bystrzycy, za jego przykładem poszło kilku innych ludzi. Działacze MOL dostrzegali w bezkarności kolejarzy poważny problem: Z tego widać, że właśnie miejscowi polscy pracownicy kolei maja w miejscach swojego pobytu i w okolicy wielu krewnych, wśród których moga tatwo pracować przeciw wszystkiemu, co czeskie ${ }^{30}$.

Niewątpliwie wśród kolejarzy pojawił się rozłam na tych, którzy chcieli zachować narodowość polską lub niemiecką i tych, którzy

\footnotetext{
${ }^{28}$ Ibidem.

${ }^{29}$ Gąsior G., Vztah Slezské matice osvěty lidové k otázce železničnich zaměstnanců na Těšinsku v obdobi první republiky, ,Slovanský přehled“ 95, 2009, č. 3, s. 381401.

${ }^{30}$ SOAFM, f. SMOL Bystřice nad Olzou, inv. č. 3, karton 1, rezolucja kolegium powiatowego SMOL dla ziemi jabłonkowskiej [z 1 grudnia 1929].
} 
woleli dostosować się do nowych warunków i nie narażać siebie ani swoich rodzin. Wbrew histerycznym apelom MOL sytuacja nie była łatwa dla przedstawicieli mniejszości narodowych. Co roku w okresie zapisów szkolnych miała miejsce ostra agitacja na rzecz czeskich, polskich i niemieckich szkół. W jej ramach stosowano nie tylko zachęty, ale także naciski i groźby. Kolejarze (i nie tylko oni) stosowali różne wybiegi, np. bronili się przed przeniesieniem swoich dzieci do czeskich szkół, argumentując, że spłacają kredyt w polskiej kasie oszczędnościowej. Z jednej strony argument ten był podnoszony przez działaczy MOL w celu wytłumaczenia słabości czeskiego życia narodowego na Śląsku Cieszyńskim, z drugiej w jednym z dokumentów zauważyli oni, że jest to tylko wymówka, gdyż kierownicy czeskich szkół są w stanie zapewnić im nowy kredyt w razie wypowiedzenia go przez Polaków ${ }^{31}$.

Informacji o postawach narodowych zawartych w dokumentach urzędów kolejowych i MOL nie można traktować bezkrytycznie. W dokumentach tych zwracano przede wszystkim uwagę na postawę prezentowaną na zewnątrz, nieraz wymuszoną okolicznościami. Poglądy niektórych kolejarzy nie zawsze są czytelne. Z pewnością występowały u nich różne wahania, wynikające zarówno z wywieranej na nich presji ze strony pracodawców, sąsiadów oraz członków rodziny. Szukali też wsparcia w różnych środowiskach. Takim przykładem był m.in. kolejarz Szczepan Macura. W jego obronie wobec szykan ze strony pracodawców stanęli zarówno przedstawiciele polskiej Subdelegacji dla Śląska Cieszyńskiego, Spisza i Orawy ${ }^{32}$, jak i posłowie mniejszości niemieckiej w czechosłowackim parlamencie ${ }^{33}$.

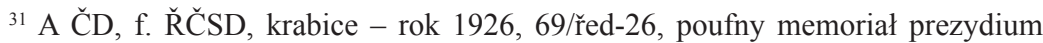
SMOL dla dyrektora Czechosłowackich Kolei Państwowych w Ołomuńcu, Viktora Polívki, z 18 grudnia 1928 r. (sic!).

${ }^{32}$ NA, f. MŽ, k. 229, raport dr. Schillera z 10 lipca 1922 r.

${ }^{33}$ Interpelace poslanců dra Lodgmana, Křepka, Böhra, inž. Junga, dra Kafky a druhů ministrovi vnitra o nezákonnostech při sčítání lidu v roce 1921, http://www.psp. cz/eknih/1920ns/ps/tisky/t3128_09.htm (dostęp: 18 października 2016 r.). 
Nie oznacza to, że ludzie typu Macury nie mieli świadomości narodowej - dokumenty nie pozwalają na tak dokładne odczytanie poglądów konkretnych ludzi. Niemcy mieli na początku lat 20. przedstawicieli w czechosłowackim parlamencie, mieli duże wpływy w życiu politycznym i gospodarczym, mieli większe możliwości ochrony swoich zwolenników (choć interwencje nie zawsze okazywały się skuteczne). W oczach wielu ludzi znajomość języka niemieckiego była też niezbędnym warunkiem awansu społecznego.

Można przyjąć, że część kolejarzy była obojętna na sprawy narodowe, trudno byłoby jednak wykazać, że przed przystąpieniem do czeskiego obozu nie mieli oni żadnej świadomości narodowej a samej zmianie orientacji nie towarzyszyły żadne rozterki. Tożsamość narodowa stanowiła tylko jeden z punktów odniesienia. W osobistej hierarchii wartości mogła stać na pierwszym, drugim lub bardziej odległym miejscu. Okoliczności stawiały ludzi przed dylematami a ostateczne wybory były wypadkową wielu czynników. Postawa przyjmowana na zewnątrz nie zawsze odpowiadała rzeczywiście wyznawanym poglądom. Jednocześnie ludzie racjonalizują swoje działania. Odchodząc od swojej narodowości pod wpływem nacisku, ulegając wpływom nowego otoczenia i na skutek narastających napięć z dawnym środowiskiem oraz nowych doświadczeń, niektórzy mogli przyjąć nową tożsamość narodową jako swoją i nawet szczerze zaangażować się na jej rzecz. Z pewnością jednak w pierwszym pokoleniu, które przystąpiło do czeskiego obozu, obecne były postawy sceptyczne, nie wyrażane głośno w obecności przełożonych. Dopiero następne pokolenie, pobierające naukę w czeskich szkołach, zapoznawało się bliżej z czeską kulturą. Pochodząca z Nawsia Marta Rulfová, uważająca się za Czeszkę, we wspomnieniach opisała swojego ojca kolejarza jako obojętnego narodowo i zniechęconego do polityki ${ }^{34}$. Postawa taka była zapewne nieobca także innym, którzy przystosowali

${ }^{34}$ Rulfová M., Slzy pro Těšinsko, Mohelnice 2006, s. 128. 
się do nowych warunków i wstępowali do czeskich organizacji, gdyż tego wymagali od nich ich przełożeni.

\section{Bibliografia}

Archiwa:

1. Archiv Českých drah v Července

- f. Košicko-bohumínská dráha

- Ředitelství ČSD v Olomouci 1895-1949

2. Národní archiv v Praze

- f. Ministerstvo železnic I, Praha

3. Státní okresní archiv Frýdek-Místek

- f. Slezská Matice osvěty lidové Bystřice nad Olzou

4. Zemský archiv Opava

- f. Slezská Matice osvěty lidové 1897-1950

Literatura:

1. Gawrecki D., Politické a národnostní poměry v Těšinském Slezsku 1918-1938, Český Těšín 1999.

2. Gąsior G., Dwa memoriały Rudolfa Matouša w sprawie czechosłowackiej polityki na Śląsku Cieszyńskim z 1920 i 1923 r. (w przygotowaniu).

3. Gąsior G., Železnice pod zvláštním dohledem: železnični úr̆ady a národnostní otázka v československé části Těšinského Slezska na začátku 20. let (planowane do publikacji).

4. Gąsior G., Vztah Slezské matice osvěty lidové $k$ otázce železničních zaměstnanců na Těšinsku v obdobi prvni republiky, ,Slovanský přehled“ 3/2009, s. 381-401.

5. Rulfová M., Slzy pro Těšínsko, Mohelnice 2006, s. 128. 